\title{
Use of High-Temperature Gas-Tight Electrochemical Cells to Measure Electronic Transport and Thermodynamics in Metal Oxides*
}

\author{
J.-H. Park, B. Ma, and E. T. Park \\ Energy Technology Division \\ Argonne National Laboratory \\ Argonne, IL 60439 U. S. A
}

\section{RECENED \\ NOV 041997 \\ 0.87}

September 1997

\footnotetext{
'The submitted manuscript has been created by the University of Chicago as Operator of Argonne National Laboratory ("Argonne") under Contract No. W-31-109-ENG-38 with the U.S. Department of Energy. The U.S. Government retains for itself, and others act-

ing on its behalf, a paid-up, nonexclusive, irrevocable worldwide license in said article to reproduce, prepare derivative works, dis-

tribute copies to the public, and perform pub-

licly and display publicly, by or on behalf of

the Government.
}

INVITED paper for publication in Korean Journal of Ceramics as a proceedings of workshop on Defect Chemical Nature of Advanced Materials, the Seoul National University, Seoul, Korea, September 29-October 1, 1997.

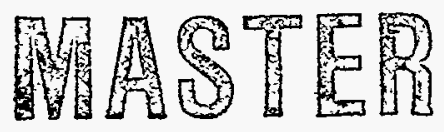

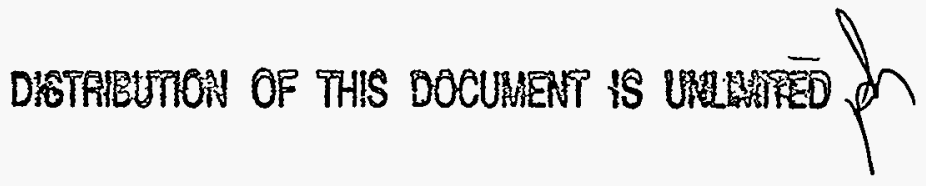

*Work supported by the US. Department of Energy, under Contract W-31-109-Eng-38. 


\section{DISCLAIMER}

This report was prepared as an account of work sponsored by an agency of the United States Government. Neither the United States Government nor any agency thereof, nor any of their employees, makes any warranty, express or implied, or assumes any legal liability or responsibility for the accuracy, completeness, or usefulness of any information, apparatus, product, or process disclosed, or represents that its use would not infringe privately owned rights. Reference herein to any specific commercial product, process, or service by trade name, trademark, manufacturer, or otherwise does not necessarily constitute or imply its endorsement, recommendation, or favoring by the United States Government or any agency thereof. The views and opinions of authors expressed herein do not necessarily state or reflect those of the United States Government or any agency thereof. 


\section{DISCLAMVIRR}

Portions of this document may be illegible in electronic image products. Images are produced from the best availabile original document. 


\title{
Use of High-Temperature Gas-Tight Electrochemical Cells to Measure Electronic Transport and Thermodynamics in Metal Oxides*
}

\author{
J.-H. Park, B. Ma, and E. T. Park \\ Energy Technology Division \\ Argonne National Laboratory \\ Argonne, IL 60439
}

\begin{abstract}
By using a gas-tight electrochemical cell, we can perform high-temperature coulometric titration and measure electronic transport properties to determine the electronic defect structure of metal oxides. This technique reduces the time and expense required for conventional thermogravimetric measurements. The components of the gastight coulometric titration cell are an oxygen sensor, Pt/yttria stabilized zirconia (YSZ)/Pt, and an encapsulated metal oxide sample. Based on cell design, both transport and thermodynamic measurements can be performed over a wide range of oxygen partial pressures $\left(\mathrm{pO}_{2}=10^{-35}\right.$ to $\left.1 \mathrm{~atm}\right)$. This paper describes the high-temperature gas-tight electrochemical cells used to determine electronic defect structures and transport properties for pure and doped-oxide systems, such as YSZ, doped and pure ceria (Ca$\mathrm{CeO}_{2}$ and $\mathrm{CeO}_{2}$ ), copper oxides, and copper-oxide-based ceramic superconductors, transition metal oxides, $\mathrm{SrFeCo}_{0.5} \mathrm{O}_{x}$, and $\mathrm{BaTiO}_{3}$.
\end{abstract}

*Work supported by the US. Department of Energy, under Contract W-31-109-Eng-38. 


\section{INTRODUCTION}

The value of directly obtaining partial molar thermodynamic quantities in the investigation of nonstoichiometric oxides is that it allows thermodynamic characterization without assuming a particular defect model. These quantities, which consist mainly of variations in oxygen chemical potential with changing temperature and composition, can best be used in support of, and in conjunction with, a proposed defect model. Together, they provide insight, understanding, and a concise description of the nonstoichiometric behavior to develop various sensors and membranes for the application of gas separation or synthesis for industry.

Of the many different measurement systems that have been used in hightemperature thermodynamic studies of metal oxides, electrochemical titration cells, which incorporate solid electrolytes, offer the greatest versatility. In previous studies of metal oxides (e.g., $\mathrm{CeO}_{2-\mathrm{x}}$ ), electron mobility $(\mu)$ was determined by combining separate experimental measurements of deviation from stoichiometry $(\mathrm{x})$ and electrical conductivity $(\sigma)$. A coulometric titration technique, which extends the utility of the titration cell to include the direct and simultaneous measurements of thermodynamic quantities and electronic conductivity, is presented. To perform the high-temperature coulometric titration technique, we must understand the nonstoichiometric defect behavior in yttria stabilized zirconia (YSZ). Therefore YSZ and nonstoichiometric cerium dioxide were chosen for the purpose of demonstration.

When a metal oxide (binary, ternary, or even quaternary oxides, in which $M, N, L$ are different nonvolatile metals), designated as $\mathrm{M}(\mathrm{NL}) \mathrm{O}_{2}$, is in equilibrium with the surrounding oxygen atmosphere at elevated temperatures, we may write the overall reaction as (only " $\mathrm{M}$ " is denoted for convenience) 


$$
\mathrm{MO}_{2}(\mathrm{~s})=\mathrm{MO}_{2-\mathrm{x}}(\mathrm{s})+\frac{\mathrm{x}}{2} \mathrm{O}_{2}(\mathrm{~g})
$$

where $\mathrm{x}$ indicates the deviation from stoichiometry. According to the Gibbs phase rule, two intrinsic parameters are needed to describe the $\mathrm{x}$ values, i.e., temperature and $\mathrm{pO}_{2}$; thus, $\mathrm{x}=\mathrm{x}\left(\mathrm{T}, \mathrm{pO}_{2}\right)$.

\subsection{Defects in Yttria-Stabilized Zirconia (YSZ)}

YZS has a stable fluorite cubic structure consisting of $\mathrm{Zr}^{+4}$ at outer face centeredcubic positions and $\mathrm{O}^{-2}$ at inner simple-cubic positions. Because the proposed defect model in metal oxide systems is similar, YSZ was chosen for the demonstration.

When $\mathrm{ZrO}_{2}$ is doped with $\mathrm{Y}_{2} \mathrm{O}_{3}$, a doubly ionized oxygen vacancy $\left(\mathrm{V}_{\mathrm{o}}^{* \bullet}\right.$ ) is produced. The defect reaction can be represented as ${ }^{1}$

$$
\mathrm{YO}_{1.5} \rightarrow \mathrm{Y}_{\mathrm{Zr}}^{\prime}+\frac{1}{2} \mathrm{~V}_{\mathrm{o}}^{\bullet \bullet}+\frac{3}{2} \mathrm{O}_{\mathrm{O}}^{\mathrm{x}}
$$

where $Y_{Z r}^{\prime}$ indicates yttrium on the zirconium site with a formal charge of -1 , and $O_{0}^{x}$ indicates normal oxygen on an oxygen site.

The formula for YSZ containing y moles of yttria is $\mathrm{Zr}_{1-y} \mathrm{Y}_{y} \mathrm{O}_{2-\mathrm{y} / 2}$. The electroneutrality condition is 2

$$
\left[\mathrm{Y}_{\mathrm{Zr}}^{\prime}\right]=4\left[\mathrm{~V}_{0}^{\cdot \bullet}\right]
$$

where the bracket indicates the site fraction of each species. When the YSZ is in equilibrium with the surrounding oxygen, the overall solid/gas reaction is

$$
\mathrm{Zr}_{1-y} \mathrm{Y}_{y} \mathrm{O}_{2-\frac{y}{2}}=\mathrm{Zr}_{1-y} \mathrm{Y}_{y} \mathrm{O}_{2-\frac{y}{2}-x}+\frac{\mathrm{x}}{2} \mathrm{O}_{2}(\mathrm{~g})
$$


The nonstoichiometric defect reactions proposed by several authors ${ }^{1-4}$ for an n-type region, i.e., at low oxygen pressure, with an enthalpy of $\Delta H^{\circ}$ are

$$
2 \mathrm{Zr}_{\mathrm{Zr}}^{\mathrm{x}}+\mathrm{O}_{\mathrm{O}}^{\mathrm{x}}=2 \mathrm{Zr}_{\mathrm{Zr}}^{\prime}+\mathrm{V}_{\mathrm{o}}^{\ddot{*}}+\frac{1}{2} \mathrm{O}_{2}(\mathrm{~g})
$$

or simply,

$$
\mathrm{O}_{\mathrm{o}}^{\mathrm{x}} \rightarrow \mathrm{V}_{\mathrm{o}}^{\bullet}+2 \mathrm{e}^{\prime}+\frac{1}{2} \mathrm{O}_{2}(\mathrm{~g})
$$

where $\mathrm{Zr}_{\mathrm{Zr}}^{\prime}$ indicates a localized electron on a zirconium site. Because of the nonstoichiometric defect reaction, the electroneutrality equation (Eq. 3) becomes

$$
4\left[\mathrm{~V}_{\mathrm{o}}^{*}\right]=\left[\mathrm{Zr}_{\mathrm{Zr}}^{\prime}\right]+\left[\mathrm{Y}_{\mathrm{Zr}}^{\prime}\right]
$$

The site fractions of localized electrons and yttrium atoms on zirconium sites may be expressed in terms of $\mathrm{x}$ and $\mathrm{y}$ as

and

$$
\begin{gathered}
{\left[\mathrm{Zr}_{\mathrm{Zr}}^{\prime}\right]=2 \mathrm{x}} \\
{\left[\mathrm{V}_{\mathrm{o}}^{*}\right]=\frac{(\mathrm{x}+\mathrm{y})}{2}}
\end{gathered}
$$

The mass action constant, $\mathrm{K}_{\mathrm{ma}}$, associated with the defect reaction, (Eq. 5a) is

$$
\mathrm{K}_{\mathrm{ma}}=\frac{\left[\mathrm{Zr}_{\mathrm{Zr}}^{\prime}\right]^{2}\left[\mathrm{~V}_{\mathrm{o}}^{*}\right]}{\left[\mathrm{Zr}_{\mathrm{zr}}^{\mathrm{x}}\right]\left[\mathrm{O}_{\mathrm{o}}^{\mathrm{x}}\right]} \mathrm{pO}_{2}^{1 / 2}
$$

On the basis of Eq. 7 and the assumption that $\left[\mathrm{Zr}_{\mathrm{zr}}^{\mathrm{x}}\right]=1-\mathrm{y}$ and $\left[\mathrm{O}_{\mathrm{o}}^{\mathrm{x}}\right]=1-(\mathrm{y} / 2), \mathrm{n} \mathrm{K} \mathrm{K}_{\mathrm{ma}}$ can be written as 


$$
\mathrm{K}_{\mathrm{ma}}=\frac{(2 \mathrm{x})^{2}[(\mathrm{x}+\mathrm{y}) / 2]}{(1-\mathrm{y})[1-(\mathrm{y} / 2)]} \mathrm{pO}_{2}^{1 / 2}
$$

By differentiating and rearranging Eq. 9, we obtain

$$
\frac{\partial \log \left(\mathrm{pO}_{2}\right)}{\partial \log (\mathrm{x})}=-4-\frac{2 \mathrm{x}}{\mathrm{x}+\mathrm{y}}
$$

When $y=0.148$ ( 8 mole \% YSZ $)$ and $y>>x$, the slope is essentially -4 . For pure oxide (no doping), i.e., $\mathrm{y}=0$, Eq. 10 becomes $\partial \log \left(\mathrm{pO}_{2}\right) / \partial \log (\mathrm{x})=-6$. For $\mathrm{ZrO}_{2}$ doped with 8 mole \% YSZ, the deviation from stoichiometry, $\mathrm{x}$, is

$$
\mathrm{x}=\mathrm{KpO}_{2}^{-1 / 4}
$$

where the proportionality constant $\mathrm{K}=1.61 \sqrt{\mathrm{K}_{\mathrm{ma}}}$. Using the thermodynamic relation $\Delta \mathrm{H}^{\circ}=\Delta \mathrm{G}^{\circ}+\mathrm{T} \Delta \mathrm{S}^{\circ}$, we may also write

$$
\mathrm{K}_{\mathrm{ma}} \propto \exp \left(-\frac{\Delta \mathrm{G}^{\circ}}{\mathrm{kT}}\right)=\exp \left(\frac{\Delta \mathrm{S}^{\circ}}{\mathrm{kT}}\right) \exp \left(-\frac{\Delta \mathrm{H}^{\circ}}{\mathrm{kT}}\right)
$$

The reaction for the formation of oxygen is

$$
\mathrm{O}_{2}(1 \mathrm{~atm}, \mathrm{~g})+4 \mathrm{Zr}_{\mathrm{Zr}}^{\prime}+2 \mathrm{~V}_{\mathrm{o}}^{\ddot{*}}=4 \mathrm{Zr}_{\mathrm{zr}}^{\mathrm{x}}+2 \mathrm{O}_{\mathrm{o}}^{\mathrm{x}}
$$

with an enthalpy of $\Delta \mathrm{H}_{\mathrm{O}_{2}}$. From Eqs. 5 and 13, it is apparent that

$$
\Delta \mathrm{H}_{\mathrm{O}_{2}}=-2 \Delta \mathrm{H}^{\mathrm{o}}
$$


When we plot the $\log \mathrm{K}$ vs. $1 / \mathrm{T}$ or $\log \mathrm{x}\left(\right.$ fixed $\mathrm{pO}_{2}$ ) vs. $1 / \mathrm{T},-\Delta \mathrm{H}^{\circ}=2$ times the slope, and therefore, $\Delta \mathrm{H}_{\mathrm{O}_{2}}$ can be obtained from 4 times the slope.

\subsection{Solid-State Coulometric Titration}

High-temperature solid-state coulometric titration of oxide systems involves the removal or addition of oxygen by means of an oxygen pump. During pumping, the solidgas reaction is represented as 3,4

$$
\mathrm{MO}_{2}(\mathrm{~s}) \underset{\text { pump-in }}{\stackrel{\text { pump-out }}{\Leftrightarrow}} \mathrm{MO}_{2-\mathrm{x}}(\mathrm{s})+\frac{\mathrm{x}}{2} \mathrm{O}_{2}(\mathrm{~g})
$$

As oxygen is pumped out of the cell (and therefore out of the specimen), one can measure the EMF, which corresponds to the equilibrium $\mathrm{pO}_{2}$ for the sample and gas. The gastight chamber incorporates an electrochemical sensor that also serves as an oxygen pump and allows for the simultaneous control of oxygen flux and measurement of oxygen potential. When pumping oxygen, two primary sources of oxygen are considered: (a) the gas phase in the cell and (b) the sample phase, which is described by Eq. 15. The total moles of oxygen pumped are denoted by $\Delta \mathrm{n}_{\mathrm{O}_{2}}$, which can be evaluated by Faraday's law:

$$
\Delta \mathrm{n}_{\mathrm{O}_{2}}=\frac{\mathrm{i} \Delta \mathrm{t}}{4 \mathrm{~F}}=\Delta \mathrm{n}_{\mathrm{O}_{2} \text { (gas) }}+\Delta \mathrm{n}_{\mathrm{O}_{2} \text { (specimen) }}
$$

where $\Delta \mathrm{n}_{\mathrm{O}_{2} \text { (gas) }}$ and $\Delta \mathrm{n}_{\mathrm{O}_{2} \text { (specimen) }}$ are the moles of oxygen pumped from the gas and specimen, respectively. To calculate the net amount of oxygen removed from the specimen, we must subtract the gas-phase contribution from the total amount of oxygen. When the gas phase is treated as an ideal gas, 


$$
\Delta \mathrm{n}_{\mathrm{O}_{2}(\mathrm{gas})}=\frac{\mathrm{V}}{\mathrm{RT}} \Delta \mathrm{pO}_{2}
$$

where $\mathrm{V}$ is the free volume of the gas-tight chamber, $\Delta \mathrm{pO}_{2}=\mathrm{pO}_{2, \mathrm{f}}-\mathrm{pO}_{2, \mathrm{i}}$, and the subscripts $f$ and $i$ are the final and initial equilibrium $\mathrm{pO}_{2}$. For the specimen,

$$
\Delta \mathrm{n}_{\mathrm{O}_{2} \text { (specimen) }}=\frac{\mathrm{W}}{2 \mathrm{M}}\left[\mathrm{x}_{\mathrm{f}}-\mathrm{x}_{\mathrm{i}}\right]
$$

where $\mathrm{W}$ is the weight of the specimen, $\mathrm{M}$ is the molecular weight, and $\mathrm{x}_{\mathrm{f}}$ and $\mathrm{x}_{\mathrm{i}}$ are the equilibrium $x$ values for a given $\mathrm{pO}_{2}$. However, when $\Delta \mathrm{n}_{\mathrm{O}_{2}(\mathrm{gas})}$ is small enough in comparison to $\Delta \mathrm{n}_{\mathrm{O}_{2} \text { (specimen), }}$, the thermodynamic behavior of the system is essentially due to the solid sample. ${ }^{3}$ If we can choose by analogy with Eq. 11 ,

and

$$
\begin{aligned}
& \mathrm{x}_{\mathrm{f}}=\mathrm{KpO}_{2, \mathrm{f}}{ }^{1 / 4} \\
& \mathrm{x}_{\mathrm{i}}=\mathrm{KpO}_{2, \mathrm{i}}{ }^{-1 / 4},
\end{aligned}
$$

where the proportionality constant $\mathrm{K}$ is the value at $\mathrm{pO}_{2}=1.0 \mathrm{~atm}$. The difference between these two states is

$$
\begin{aligned}
\Delta \mathrm{x} & =\mathrm{x}_{\mathrm{f}}-\mathrm{x}_{\mathrm{i}}=\mathrm{K}\left[\mathrm{pO}_{2, \mathrm{f}}-\mathrm{pO}_{2, \mathrm{i}}\right]^{-1 / 4} \\
& =\mathrm{K} \Delta \mathrm{pO}_{2}^{-1 / 4}
\end{aligned}
$$

and the proportionality constant $\mathrm{K}$ can be determined from Eq. 20.20

\subsection{Constant-Composition Measurement}

In a gas-tight cell at low oxygen pressures, the thermodynamics of the system are essentially determined by the solid sample. ${ }^{3}$ In this condition, we can apply the Gibbs- 
Helmholtz equation, 5

$$
\Delta \mathrm{H}_{\mathrm{O}_{2}}=\Delta \mathrm{G}_{\mathrm{O}_{2}}+\mathrm{T} \Delta \mathrm{S}_{\mathrm{O}_{2}}
$$

where $\Delta \mathrm{G}_{\mathrm{O}_{2}}=-4 \mathrm{FE}$, and $\Delta \mathrm{S}_{\mathrm{O}_{2}}=-\left(\partial \Delta \mathrm{G}_{\mathrm{O}_{2}} / \partial \mathrm{T}\right)_{\mathrm{x}=\text { const }}=4 \mathrm{~F}(\partial \mathrm{E} / \partial \mathrm{T})_{\mathrm{x}=\text { const }}$. Therefore,

$$
\begin{aligned}
\Delta \mathrm{H}_{\mathrm{O}_{2}} & =-4 \mathrm{FE}+4 \mathrm{FT}(\partial \mathrm{E} / \partial \mathrm{T})_{\mathrm{x}=\text { const }} \\
& =-4 \mathrm{~F}\left[\mathrm{E}-\mathrm{T}(\partial \mathrm{E} / \partial \mathrm{T})_{x=\text { const }}\right] .
\end{aligned}
$$

Thus, the relative partial molar enthalpy $\Delta \mathrm{H}_{\mathrm{O}_{2}}$ and the relative partial molar entropy $\Delta \mathrm{S}_{\mathrm{O}_{2}}$ can be determined from the changes in EMF with temperature at constant $\mathrm{x}$; or from, respectively, the slope of $\log \mathrm{pO}_{2}$ vs. $1 / \mathrm{T}$, i.e.,

$$
\Delta \mathrm{H}_{\mathrm{O}_{2}}=\mathrm{R}\left[\partial \ln \mathrm{pO}_{2} / \partial(1 / \mathrm{T})\right]_{\mathrm{x}=\text { const }}
$$

and $\Delta \mathrm{S}_{\mathrm{O}_{2}}$, the intercept at $1 / \mathrm{T}=0$.

\subsection{Electronic Transport Properties}

The electronic conductivity $(\sigma)$

$$
\sigma=n q \mu
$$

where $\mathrm{n}$ is the electron concentration, and $\mu$ the electron mobility. The mobility is expressed as

$$
\mu=\mu_{\mathrm{o}} \exp \left(-\frac{E_{\mathrm{m}}}{\mathrm{kT}}\right),
$$


where $\mu_{\mathrm{o}}$ is a pre-exponential constant, and $\mathrm{E}_{\mathrm{m}}$ is the migration energy of electrons. In fluorite structures, such as ceria, the concentration of electrons ( $n$ ) can be denoted as

$$
\mathrm{n}=\frac{8 \mathrm{x}}{\mathrm{a}_{\mathrm{o}}^{3}}
$$

where $a_{o}$ is the X-ray lattice parameter. By combining Eqs. 24-26, we obtain

$$
\sigma=\frac{8 x}{a_{0}^{3}} q \mu_{0} \exp \left(-\frac{E_{m}}{k T}\right) .
$$

\subsection{Electrochemical Transport}

Heyne ${ }^{6}$ derived the electrochemical transport equation for ambipolar transport in metal oxides under a chemical potential gradient

$$
-\mathrm{j}_{\mathrm{e}}=\mathrm{j}_{\mathrm{i}}=\left(\sigma_{\mathrm{t}} / 4 \mathrm{q}\right) \mathrm{t}_{\mathrm{i}} \mathrm{t}_{\mathrm{e}}\left(\partial \mu_{\mathrm{O}_{2}} / \partial \mathrm{x}\right)
$$

For ionic conductors, $t_{i}>t_{e}$, i.e., $t_{i} \sim 1$, it gives

$$
\mathrm{j}_{\mathrm{i}}=\left(\sigma_{\mathrm{e}} / 4 \mathrm{q}\right)\left(\partial \mu_{\mathrm{o}_{2}} / \partial \mathrm{x}\right)
$$

For electronic conductors, $t_{e} \gg t_{i}$, i.e., $t_{e} \sim 1$, it gives

$$
\mathrm{j}_{\mathrm{i}}=\left(\sigma_{\mathrm{i}} / 4 \mathrm{q}\right)\left(\partial \mu_{\mathrm{O}_{2}} / \partial \mathrm{x}\right)
$$

\section{EXPERIMENTAL APPROACH}

\subsection{Experimental Equipment}




\section{Electrochemical Cell Construction}

Various designs of gas tight electrochemical cells are shown in Fig. 1. In Fig. 1a, two identical YSZ disks are used. The top disk of the cell serves as a permeation specimen and as an oxygen sensor. The bottom disk is primarily used as an oxygen pump. The walls of the cell consist of three 0.5-in.-diameter high-purity alumina (\#998A, McDanel) rings that are separated from each other and the disks by thin Pyrex glass (\#7740, Corning) rings. The alumina rings also provide high-temperature electrical insulation. Both YSZ disks were painted with platinum paste (code \#6926 unfluxed, Engelhard) on the entire outer face and on that part of the inner face that would be within the enclosure. These electrodes were further prepared in air by several heating step, finally being fired at $\approx 980^{\circ} \mathrm{C}$ overnight. Platinum wires of 5 mil-diameter were used as electric leads in the Pyrex-sealed cell. The entire stack was placed in the measuring furnace along a vertical axis and a spring force was applied to the stack. A $3 \% \mathrm{O}_{2} / \mathrm{Ar}$ gas mixture was passed through the system while firing up to $1000^{\circ} \mathrm{C}$. During heating, the Pyrex g (softening temperature $820^{\circ} \mathrm{C}$ ) rings melted and provided a gas-tight seal. The limitation of mechanical pressure difference in the Pyrex seal was $0.35 \mathrm{~atm}$ at $920^{\circ} \mathrm{C}$. This was determined by the continuous pumping in of oxygen through the electrolyte until failure. However, when the oxygen was pumped out from the inside cell, the maximum pressure obtainable was 0.03 atm because the initial gas mixture was $3 \% \mathrm{O}_{2}$-Ar. No problem in sealing was experienced when pumping oxygen out.

\section{Four- Probe Conductivity Cell}

The various conductivity specimens were prepared by sintering. The final step was to cut the bar into a four-probe conductivity specimen and load it into the coulometric titration chamber shown in Fig. 1b. Both DC and AC conductivity can be measured; the $\mathrm{AC}$ conductivity was measured at a constant frequency of $1592 \mathrm{~Hz}$. 


\section{Measuring Assembly}

The electrochemical cell was placed an alumina tube of $3.8 \mathrm{~cm}$ outer diameter (OD). and $35 \mathrm{~cm}$ length, with a flat disc end. An open window measuring $2.5 \times 5 \mathrm{~cm}$ was cut in the bottom of the alumina tube for installation of the electrochemical cell. This portion was sealed to the brass head with water-soluble high-temperature ceramic cement (Paste \#1, Sauereisen Cement Co.) and then inserted into a quartz tube. The quartz (outer) tube was $36 \mathrm{~cm}$ in length and $4.5 \mathrm{~cm}$ in OD. It was connected to the brass head by an Oring to form a gas-tight system. A spring-loaded alumina rod was loaded onto the cell stack to facilitate sealing. A thermocouple made of $16 \mathrm{mil} \mathrm{Pt}-13 \% \mathrm{Rh} / \mathrm{Pt}$ in a $6 \mathrm{~mm}$ OD thermocouple tube was inserted into the 0.5 -in. diameter alumina tube. A heat resistant alloy (Inconel) tube was placed in the furnace outside the measuring system. To protect it from electrical pickup, the alloy tube was grounded; serving as a heat sink, it also acts to provide a more uniform temperature.

\subsection{Cell Performance Tests}

To perform electrochemical transport measurements utilizing a Pyrex-glass-sealed gas-tight cell, the following preliminary tests were necessary.

\section{Leak Test by Switching Gas}

After sealing the cell, the Pyrex seals by switching the gas outside of the cell from $3 \% \mathrm{O}_{2}-\mathrm{Ar}$ (original atmosphere) to $\mathrm{O}_{2}$ (or air). If the seals are gas-tight the EMF should correlate with the oxygen potential difference within experimental error. If there are open pores or leakage is present, the indicating EMF will drop rapidly to zero after switching gas. The leak test was performed $\approx 900^{\circ} \mathrm{C}$. The successful seals showed no significant change in EMF with time.

\section{Cell Volume Measurement by Coulometric Titration}


The free volume of the electrochemical cell can be determined by coulometric titration. With the ideal gas law, $\mathrm{PV}=\mathrm{nRT}$, or $\Delta \mathrm{pO}_{2} \mathrm{~V}=\Delta \mathrm{n}_{\mathrm{O}_{2}} \mathrm{RT}$ when supplying current, $\Delta \mathrm{n}_{\mathrm{O}_{2}}=\mathrm{i} \cdot \mathrm{t} / 4 \mathrm{~F}$ and or, from the plot of $\mathrm{pO}_{2}$ vs. time, $\mathrm{t}$, the slope gives

$$
\text { slope }=\left(\partial \mathrm{pO}_{2} / \partial \mathrm{t}\right)=(\mathrm{iRT} / 4 \mathrm{~F}) / \mathrm{V}
$$

To determine the $\mathrm{pO}_{2}$ range for which the above expressions are valid, a gas coulometric titration experiment was performed. The continuous pumping profile of $\mathrm{pO}_{2}$ ranges from $\approx 0.2 \mathrm{~atm}$ to $\approx 10^{-6} \mathrm{~atm}$ at $982^{\circ} \mathrm{C}$. Also from the plot, one can see that the calculated volumes at various points are relatively constant until the $\mathrm{pO}_{2}$ is $\approx 10^{-3}$ atm at $982^{\circ} \mathrm{C}$. Focusing on the $\mathrm{pO}_{2}$ region of air $(0.21 \mathrm{~atm})$, we attempted several runs to determine volume by two approaches. For these experiments, an additional monitor (Fig. 1c) was added to the cell. The first approach utilized only one disc as an oxygen pump. From a plot of $\mathrm{pO}_{2}$ vs. time for this case one obtains a volume of $2.15 \mathrm{~cm}^{3}$. In each case the average volume was within $0.5 \%$ of the individual runs.

\section{Pumping Performance Tests}

The above coulometric titration test can be used to accurately determine ionic transference numbers near 1. EMF or conductivity methods do not provide the accuracy obtainable by coulometric titration. The following experiments were carried out to determine the relative ionic transference number of various samples.

Using a three monitor cell (Fig. 1c), we evaluated the pumping performance of YSZ by supplying identical current to each of the two discs. A continuous pumping system was used, with one side pumping oxygen out and the other side pumping oxygen in. Tests were also conducted in the reverse direction. No change in EMF was noted when identical composition ZDY-2(YSZ) discs were used. However, when other YSZ discs were used (ZDY-4 [YSZ] and ZDY-2[YSZ]), changes in EMF were noted which 